\title{
Analisis Kualitas Penerapan Good Corporate Governance dan Kinerja PT Bank Mandiri (Persero) Tbk
}

\author{
Oleh: \\ Elvis Ronald Sumanti \\ Agus Tony Poputra
Program Pendidikan Profesi Akuntansi
Fakultas Ekonomi dan Bisnis
Universitas Sam Ratulangi Manado
Email : elvis_sumanti@yahoo.com

\begin{abstract}
ABSTRAK
Tujuan dari laporan akhir ini adalah untuk menganalisis kualitas penerapan Good Corporate Governance dan kinerja PT Bank Mandiri (Persero) Tbk dengan menggunakan rasio CAMEL. Hasil penelitian ini adalah (i) kualitas penerapan GCG masih berada pada kategori sangat baik walaupun ada penurunan dibanding tahun 2011 (ii) Capital Quality mengalami peningkatan (iii) Asset Quality mengindikasikan adanyakenaikan resiko tapi dapat ditangani dengan baik (iv) Management Quality mengalami peningkatan dalam efisiensi biaya (v) Earnings Quality mengalami peningkatan seperti yang diukur dengan ROA dan ROE (vi) Liquidity berpotensi mengalami gangguan karena adanya kenaikan LDR, tapi potensi masalah telah ditangani dengan baik (vii) Secara keseluruhan kinerja perusahaan yang digambarkan oleh rasio CAMEL pada 2012 mengalami peningkatan dibandingkan tahun 2011.

Kata Kunci: Good Corporate Governance, CAMEL, rasio kecukupan modal, rasio kredit yang diberikan terhadap aset produktif, rasio kredit bermasalah, rasio imbal hasil rata-rata aset, rasio imbal hasil rata-rata ekuitas, rasio biaya operasional terhadap pendapatan operasional, loan to deposit ratio
\end{abstract}

\section{ABSTACT}

This final report aims to analyze the quality of Good Corporate Governance implementation and performance of PT Bank Mandiri (Persero) Tbk by using CAMEL ratio. The findings are (i) GCG implementation quality is still categorized as very good regardless of the slight decline in its composite value (ii) capital adequacy has increased (iii) asset quality indicates an increasing risk yet manageable (iv) management quality shows improvement in cost efficiency (v) earnings quality has shown improvement as proxied by ROA and ROE (vi) liquidity poses a potential problem as LDR rises. Nevertheless, company could manage the risk well. Overall, the bank performance in 2012 is better than 2011 as measured by CAMEL ratios.

Keywords: Good Corporate Governance, CAMEL, capital adequacy ratio, loan to productive asset ratio, nonperforming loan ratio, return on asset, return on equity, operational cost to operational revenua ratio, loan to deposit ratio 


\section{A. PENDAhuluan}

Kinerja bank merupakan faktor yang penting dalam pertumbuhan ekonomi suatu negara karena fungsinya sebagai perantara keuangan(King dan Levine, 2003).

Oleh karena itu, untuk memperkuat stabilitas industri perbankan adalah dikeluarkannya Pedoman Umum Good Corporate Governance (GCG) Perbankan Indonesia pada tahun 2004.Pedoman ini menegaskan bahwa penerapan GCG merupakan persyaratan yang mutlak untuk memperoleh dan mempertahankan kepercayaan publik dan juga menjadikan bank menjadi lebih kompetitif.

Penerapan GCG dalam perbankan dapat diimplementasikan dengan adanya struktur manajemen resiko termasuk sistem pengendalian intern (SPI).Penyelenggaraan SPI yang efektif akan meningkatkan kualitas penerapan GCG di Indonesia. Kualitas penerapan GCG dapat diukur denganswa penilaian yang dilakukan oleh bank terkait sebagaimana diatur dengan Surat Edaran Bank Indonesia Nomor15/15/DPNP tanggal $29 \quad$ April 2013perihal Pelaksanaan Good Corporate Governance Bagi Bank Umum.

Tujuan publikasi GCG Index ini adalah untuk meyakinkan investor dan juga sebagai pemicu perusahaan dalam meningkatkan kualitas penerapan konsep GCG melalui perbaikan yang berkesinambungan dengan melaksanakan evaluasi dan melakukan studi banding(IICG, 2002). Salah satu tujuan penerapan GCG adalah supaya kinerja perusahaan akan dapat meningkat dari waktu ke waktu. Kinerja perusahaan dapat diukur dengan menggunakan rasio CAMEL.Pengukuran kinerja keuangan dengan menggunakan rasio CAMEL telah mencakup penilaian kuantitatif maupun kualitatif.Rasio CAMELterdiri atas lima kriteria yaitu modal, aktiva, manajemen, pendapatan dan likuiditas.

Dengan memperhatikan pentingnya penerapan GCG terhadap stabilitas dan peningkatan kinerja bank dan membuat bank menjadi lebih kompetitif, maka dibuatlah laporan akhir ini dengan judul "AnalisisKualitas Penerapan Corporate Governance dan Kinerja PT Bank Mandiri (Persero) Tbk".

\section{B. PERUMUSAN MASALAH}

Dengan mempertimbangkan judul laporan akhir seperti yang telah dicantumkan dalam sub bab alasan pemilihan judul, maka dirumuskan pertanyaan penelitian bagaimanakah kualitas penerapan Good Corporate Governance serta kinerja PT Bank Mandiri (Persero) Tbk selama tahun 2011 dan 2012?

\section{LANDASAN TEORI}

\section{Good Corporate Governance}

Menurut PBI No. 8/14/PBI/2006, Good Corporate Governance (GCG) didefinisikan sebagai suatu tata kelola bank yang menerapkan prinsip-prinsip keterbukaan (transparency), akuntabilitas (accountability), pertanggungjawaban (responsibility), independensi (independency), serta kewajaran (fairness). GCG juga dapat diartikan sebagai suatu proses dan struktur yang digunakan untuk meningkatkan keberhasilan usaha dan akuntabilitas perusahaan yang bertujuan untuk meningkatkan nilai perusahaan dalam jangka panjang dengan memperhatikan kepentingan pemilik serta berlandaskan peraturan dan prinsip yang sesuai dengan perundang-undangan GCG.

PBI No 8/14/PBI/2006 menegaskan tentang perlunya peningkatan kualitas pelaksanaan karena besarnya resiko dan tantangan yang dihadapi oleh bank baik dari lingkungan internal maupun eksternal. Dalam menerapkan prinsip tata kelola perusahaan yang baik diperlukan suatu struktur yang kuat yang mampu bertindak sebagai panutan dan motor penggerak agar penerapan GCG dapat berjalan secara optimal.

Organization for Economic Co-operation and Development (OECD) mendefinisikan GCG sebagai sekumpulan hubungan antara pihak direksi perusahaan, komisaris, pemegang saham dan pihak lain yang memiliki kepentingan dengan perusahaan. Hubungan pihak-pihak yang terkait ini akan diatur dengan 
suatu struktur perusahaan dan perangkatnya untuk mencapai tujuan dan pengawasan atas performa yang baik(OECD, 2010).

Sehubungan dengan struktur perusahaan, perangkat dan tujuan yang akan dicapai, Komite Cadbury (1992) mendefinisikan GCG sebagai prinsip yang mengarahkan dan mengendalikan perusahaan agar mencapai keseimbangan antara kekuatan serta kewenangan perusahaan dalam memberikan pertanggungjawabannya kepada para shareholders khususnya, dan stockholders pada umumnya.

Penerapan GCG di Indonesia dapat diukur dengan menggunakan index yang secara periodik diterbitkan oleh The Indonesian Institute for Corporate Governance (IICG) sebagai salah satu pihak independen yang didirikan dengan tujuan untuk mensosialisasikan konsep dan keuntungan penerapan GCG.Secara periodik IICG menilai dan mempublikasikan indeks yang menjadi gambaran kualitas penerapan GCG dari perusahaan yang dinilai.

Selain mengukur kualitas penerapan GCG dengan indeks atau model yang dikembangkan oleh pihak independen, pemerintah melalui Peraturan Bank Indonesia Nomor 6/10/PBI/2004 mengharuskan pihak bank untuk membuat swa penilaian dengan membentuk sebuah model sendiri yang memuat prinsipprinsip GCG (Bank Indonesia, 2004).Hasil swa penilaian, yang dikenal dengan Corporate Governance Index (CGI) (penilaian terhadap diri sendiri) harus dipublikasikan bersama-sama dengan laporan keuangan yang telah diaudit secara periodik oleh bank yang bersangkutan.

\section{Bank}

Undang-undang Republik Indonesia Nomor 10 tahun 1998 dalam pasal 1 mendefinisikan bank sebagai "badan usaha yang menghimpun dana dari masyarakat dalam bentuk simpanan dan menyalurkan kepada masyarakat dalam bentuk kredit dan atau bentuk-bentuk lainnya dalam rangka meningkatkan taraf hidup rakyat banyak". Lebih lanjut, UU Nomor 10 Tahun 1998 dalam pasal 3 menyatakan fungsi perbankan adalah untuk menghimpun dan menyalurkan dana dari dan kepada masyarakat serta menunjang pelaksanaan pembangunan nasional untuk mencapai pemerataan, pertumbuhan ekonomi, dan stabilitas nasional kea rah peningkatan kesejahteraan rakyat banyak.

\section{Kinerja Bank}

Kesehatan atau kondisi keuangan bank dapat diukur dengan menggunakan rasio CAMEL. CAMEL (terdiri atas lima kriteria yaitu modal, aktiva, manajemen, pendapatan dan likuiditas) merupakan aspek yang paling banyak berpengaruh terhadap kondisi keuangan atau kinerja bank yang kelak mempengaruhi kondisi kesehatan bank (Institut Bankir Indonesia, 1999).

Komponen $\mathrm{C}$ pada CAMEL merujuk kepada capital atau modal yang menunjukkan kemampuan bank dalam menjaga permodalannya sebanding dengan karakteristik bank dan besaran semua resiko serta bagaimana bank tersebut mengidentifikasikan, mengukur, memonitor serta mengendalikan resiko-resiko yang dihadapi(Koch dan Scott, 2003).Baral (2005) menambahkan bahwa capital adequacy dapat menunjukkan kemampuan institusi keuangan dalam mengatur kejutan atau tekanan yang tiba-tiba terhadap laporan keuangan dalam hal ini neraca.

Dalam Peraturan Bank Indonesia Nomor 6/10/PBI/2004 tentang Sistem Penilaian Tingkat Kesehatan Bank Umum, penilaian terhadap faktor permodalan meliputi "kecukupan, komposisi dan proyeksi permodalan serta kemampuan permodalan bank dalam mengcover aset bermasalah". Komponen ini dapat diproksikan dengan rasio kecukupan modal atau capital adequacy ratio.

Komponen A pada CAMEL adalah kualitas aset yang menurut Syahyunan (2002) didefinisikan sebagai penanaman bank dalam bentuk kredit yang diberikan, surat berharga, penyertaan dan penanaman lainnya yang sejenis dengan tujuan untuk memperoleh penghasilan berupa bunga yang diperoleh dari nasabah atas kredit atau sejenisnya yang diberikan. Koch dan Scott (2003) serta Singh dan Kohli (2006) lebih lanjut menegaskan bahwa kualitas aset menyediakan informasi mengenai resiko kredit yang ada maupun yang berpotensi terjadi menyangkut pinjaman yang diberikan dan juga portfolio investasi sebagaimana juga aktivitas lain yang tidak termasuk dalam neraca. 
Peraturan Bank Indonesia Nomor 6/10/PBI/2004 tentang "Sistem Penilaian Tingkat Kesehatan Bank Umum" menyatakan bahwa penilaian terhadap kualitas aset harus meliputi komponen-komponen "kualitas aktiva produktif, konsentrasi eksposur risiko kredit, perkembangan aktiva produktif bermasalah, dan kecukupan penyisihan penghapusan aktiva produktif (PPAP)". Pengukuran terhadap kualitas aset dari suatu bank menurut Surat Edaran Bank Indonesia Nomor 3/30/DPNP tanggal 14 Desember 2001 dapat menggunakan rasionon-performing loan serta rasio kredit yang diberikan terhadap aset produktif.

Komponen M pada CAMEL merujuk pada kualitas manajemen dari suatu bank.Manajemen yang baik dari suatu bank merupakan suatu faktor penentu dari kinerja bank meskipun ukuran yang tepat untuk mengukur kualitas manajemen sulit untuk ditentukan karena adanya unsur subyektivitas dalam pengukuran tersebut(Baral, 2005). Manajemen yang berkualitas akan mampu untuk mengidentikasikan, mengevaluasi, memonitor serta mengendalikan resiko-resiko yang muncul sebagai konsekuensi dari kebijakan-kebijakan yang dibuat oleh manajemen dalam mencapai target yang telah ditetapkan (Kuncoro, 2006).

Melalui Peraturan Bank Indonesia Nomor 6/10/PBI/2004 tentang Sistem Penilaian Tingkat Kesehatan Bank Umum, pemerintah telah menyatakan komponen-komponen yang akan dinilai dalam mengukur kualitas manajemen. Komponen itu mencakup manajemen umum, penerapan sistem manajemen resiko serta kepatuhan Bank terhadap ketentuan yang berlaku. Rasio BOPO (beban operasional terhadap pendapatan operasional) akan digunakan untuk mengukur kinerja manajemen dalam efektifitas dan efisiensi biaya untuk menghasilkan profit (Baral, 2005).

Komponen E pada CAMEL merefleksikan kualitas earnings (rentabilitas) sebagai indikator tren, jumlah juga faktor-faktor yang akan menunjang rentabilitas (Koch dan Scott, 2003), menyatakan bahwa rentabilitas juga dapat menjadi indikator tentang kesehatan bank, kapasitas pertumbuhan serta kemampuan perusahaan dalam menjalankan bisnisnya saat ini dan melaksanaan operasinya pada waktu yang akan datang( Singh dan Kohli, 2006 dan Sarker ,2006).

Pemerintah melalui Peraturan Bank Indonesia Nomor 6/10/PBI/2004 tentang Sistem Penilaian Tingkat Kesehatan Bank Umum menyatakan bahwa Return on Assets, dan Return on Equitydapat dijadikan proksi dari rentabilitas

Komponen L pada CAMEL atau likuiditas menunjukkan ketersediaan dana serta sumber dana dari bank pada saat ini dan waktu yang akan datangserta ketahanan bank(Kuncoro, 2006),khususnya ketika adanya penarikan dana dari deposan yang tidak diantisipasi sebelumnya (Hays, De Lurgio, Gilbert Jr., 2009).

Peraturan Bank Indonesia Nomor 6/10/PBI/2004 tentang Sistem Penilaian Tingkat Kesehatan Bank Umum menyatakan bahwa penilaian terhadap faktor likuiditas harus mencakup komponenkomponen yang dinyatakan oleh "rasio aktiva/pasiva likuid, potensi maturity mismatch, kondisi loan to deposit ratio, proyeksi cash flow, dan konsentrasi pendanaan". Loan to deposit ratio dan non performing loan dapat dijadikan proksi untuk mengukur likuiditas bank.

\section{METODE PENELITIAN \\ Karakteristik Penelitian}

Penelitian ini bersifat deskriptif yaitu memberikan gambaran mengenai kualitas penerapan GCG dan kinerja bank dengan menggunakan analisis rasio-rasio CAMEL.Unit analisis obyek penelitian ini adalah individual yaitu penelitian yang dilakukan hanya terhadap satu perusahaan saja yaitu PT Bank Mandiri (Persero) Tbk.

Data yang digunakan pada penelitian ini adalah data sekunder yaitu dengan memperoleh data-data yang relevan melalui laporan keuangan yang dipublikasikan oleh PT Bank Mandiri (Persero) Tbk. Selain itu, bahan-bahan dari buku-buku dan internet menjadi referensi dalam melakukan analisis. 


\section{Metode Analisis}

Dalam penelitian pustaka ini, analisis dilakukan terhadap laporan keuangan PT Bank Mandiri (Persero) Tbk. dengan menggunakan 5 rasio keuangan maupun hasil penilaian self-assessment pelaksanaan GCG untuk tahun 2011 dan 2012.Rasio-rasio keuangan yang akan dianalisis adalahrasio kecukupan modal (mengukur capital adequacy), rasio kredit bermasalah dan rasio kredit yang diberikan terhadap aset produktif (mengukur asset quality), rasio beban operasional terhadap pendapatan operasional (BOPO) (mengukur management quality), rasio imbal hasil rata-rata aset (ROA) dan imbal hasil rata-rata ekuitas (ROE) (untuk mengukur earnings quality), sertaloan-to-deposit ratio (mengukur liquidity).

\section{PEMBAHASAN}

\section{Good Corporate Governance Index}

Setiap tahun PT Bank Mandiri (Persero) Tbk melakukan penilaian terhadap 11 aspek penilaian yang telah ditentukan oleh Bank Indonesia.Standar penilaian menyatakan bahwa semakin kecil nilai komposit, semakin baik pula. Dengan demikian, nilai komposit menjadi lebih besar yang berarti berkurangnya kualitas penerapan GCG (Tabel D.1)

Analisis terhadap laporan manajemen dalam laporan keuangan menunjukkan bahwa tren menurun dari penerapan GCG ini disebabkan oleh pertama karena adanya benturan kepentingan. Walaupun prosedur penanganan benturan kepentingan telah diatur, namun kemungkinan tetap ada celah-celah yang dimanfaatkan oleh pihak yang berkepentingan.Selain itu, prosedur yang telah dikembangkan mungkin masih perlu dikembangkan karena belum dapat menyelesaikan semua benturan kepentingan yang muncul.

Aspek lain penyebab penurun nilai komposit GCG adalah penerapan fungsi kepatuhan bank. Penurunan ini muncul akibat adanya pelanggaran kepatuhan bank terhadap peraturan yang berlaku walaupun tidak material, juga berkurangnya sikap indepedensi. Aspek berikutnya yang mengalami penurunan peringkat adalah Penerapan Fungsi Audit Intern. Walaupun PT Bank Mandiri (Persero) Tbk menyatakan bahwa pelaksanaan Fungsi Audit Intern Bank telah berjalan efektif dan pedoman intern telah dijalankan sesuai dengan standar minimum yang telah ditetapkan, namun Bank Mandiri melihat adanya peluang untuk meningkatkan efektifitas pelaksanaan fungsi audit intern.

Aspek penyebab penurunan nilai GCG adalah adalah Transparansi Kondisi Keuangan dan Non Keuangan Bank, Laporan pelaksanaan GCG dan laporan internal.Catatan Bank Mandiri menyatakan bahwa aspek ini mengukur transparansi bank dalam melaporkan laporan keuangan maupun non keuangan kepada publik melalui homepagenya.Laporan ini harus dilakukan secara utuh, kini dan tepat waktu sesuai dengan ketentuan yang berlaku.Penurunan peringkat mengindikasikan adanya pelanggaran terhadap transparansi ataupun ketepatan waktu.

Tabel D.1 Variabel-variabel penelitian dan hasilnya

\begin{tabular}{|c|c|c|c|c|}
\hline \multirow{2}{*}{ Variabel } & \multirow{2}{*}{ Indikator } & \multicolumn{2}{|c|}{ Tahun } & \multirow{2}{*}{ Keterangan } \\
\hline & & 2011 & 2012 & \\
\hline GCG & GCG Index & 1.08 & 1.48 & $\begin{array}{l}\text { Sangat } \\
\text { Baik }\end{array}$ \\
\hline $\begin{array}{l}\text { Capital } \\
\text { Adequacy }\end{array}$ & Rasio kecukupan modal & $15.13 \%$ & $15.48 \%$ & Baik \\
\hline $\begin{array}{l}\text { Asset } \\
\text { Quality }\end{array}$ & $\begin{array}{l}\text { Rasio kredit yang diberikan } \\
\text { terhadap aset produktif }\end{array}$ & $62.81 \%$ & $67.38 \%$ & Berisiko \\
\hline
\end{tabular}




\begin{tabular}{|l|l|c|c|c|} 
& Rasio kredit bermasalah & $2.20 \%$ & $1.90 \%$ & Baik \\
\hline $\begin{array}{l}\text { Management } \\
\text { Quality }\end{array}$ & $\begin{array}{l}\text { Rasio biaya operasional } \\
\text { terhadap pendapatan } \\
\text { operasional }\end{array}$ & $54.01 \%$ & $53.20 \%$ & Baik \\
\hline $\begin{array}{l}\text { Earnings } \\
\text { Quality }\end{array}$ & Imbal hasil rata-rata aset & $2.22 \%$ & $2.44 \%$ & Baik \\
\cline { 2 - 5 } & Imbal hasil rata-rata ekuitas & $19.55 \%$ & $20.26 \%$ & Baik \\
\hline Liquidity & Loan-to-deposit ratio & $80.06 \%$ & $86.49 \%$ & Berisiko \\
\hline
\end{tabular}

Aspek terakhir yang mengalami penurunan peringkat adalah Rencana Strategis Bank. Secara umum aspek ini menyatakan mengenap kerealistisan penyusunan rencana korporasi dan rencana bisnis bank dengan memperhatikan faktor eksternal maupun internal, faktor kehati-hatian serta visi dan misi perusahaan. Penurunan peringkat swa penilaian ini dapat disebabkan oleh karena perubahan-perubahan yang sangat dinamis dan cepat serta sulitnya untuk membuat prediksi karena tingkat ketidakpastian yang sangat tinggi di lingkungan keuangan nasional maupun global.

Dengan demikian, walaupun secara keseluruhan berdasarkan swa penilaian PT Bank Mandiri (Persero) Tbk menunjukkan bahwa kualitas penerapan GCG masih tergolong "sangat baik", namun tren menunjukkan adanya penurunan kualitas dalam penerapannya pada tahun 2012 dibandingkan dengan 2011.

\section{AnalisisCapital Adequacy}

Rasio kecukupan modal adalah rasio yang menggambarkan kapasitas bank untuk memenuhi kewajiban-kewajiban dan menghadapi risiko-risiko yang dihadapi seperti risiko kredit, risiko operasional dan risiko lainnya. Bank Indonesia melalui Peraturan Bank Indonesia Nomor 14/8/PBI/2012 tentang Kewajiban Penyediaan Modal Minimum Bank Umum menyatakan bahwa untuk bank dengan profil risiko peringkat 1 (satu) harus menyediakan modal minum paling rendah $8 \%$. Untuk bank dengan profil risiko peringkat 2 adalah $9 \%$, peringkat 3 adalah $10 \%$ dan peringkat 4 sebesar $11 \%$. Bank Indonesia juga berhak untuk meminta penyediaan modal lebih dari peraturan tersebut untuk bank tertentu yang dinilai berpotensi mengalami kerugian yang besar.

Hasil penghitungan sebagaimana diperlihatkan pada Tabel D.1menunjukkan bahwa rasio kecukupan modal pada tahun 2012 mengalami peningkatan dibandingkan dengan tahun sebelumnya yaitu dari $15.13 \%$ menjadi 15.48\%. Rasio yang dicapai selama tahun 2011 dan 2012 rasio ini lebih tinggi dari yang ditetapkan oleh Bank Indonesia. Dengan demikian, PT Bank Mandiri (Persero) Tbk mampu untuk menyerap kerugian ataupun kejutan-kejutan yang berpotensi mengganggu stabilitas operasi perusahaan. Dengan rasio diatas $8 \%$ seperti yang ditetapkan oleh Peraturan Bank Indonesia, nasabah dapat dilindungi dari risiko-risiko yang mengancam kelanjutan operasi PT Bank Mandiri (Persero) Tbk.

\section{Analisis Asset Quality}

Analisis kualitas aset akan diukur dengan menggunakan dua rasio yaitu rasio kredit yang diberikan terhadap aset produktif dan rasio kredit bermasalah.

1. Rasio kredit yang diberikan terhadap aset produktif

Kualitas aset atau juga aktiva produktif didefinisikan sebagai penanaman Bank dalam bentuk kredit yang diberikan, efek-efek, penyertaan dan penanaman lainnya yang bertujuan untuk 
mendapatkan bunga dari nasabah atas kredit yang diberikan (Syahyunan, 2002).Kualitas aset dapat memberikan informasi mengenai risiko yang bakal dihadapi oleh bank.

Pada Tabel D.1 diperlihatkan bahwa rasio kredit yang diberikan terhadap aktiva produktif Bank Mandiri dari tahun 2011 ke 2012 menunjukkan adanya peningkatan dari 62.81\% menjadi $67.38 \%$. Artinya dari dana yang didapatkan dan diinvestasikan, semakin banyak yang disalurkan dalam bentuk kredit. Hal ini menunjukkan adanya peningkatan resiko dari kualitas aset Bank Mandiri.Konsep keuangan yang menyatakan bahwa investasi dengan risiko tinggi berpotensi untuk mendatangkan keuntungan yang tinggi mungkin menjadi pertimbangan dari Bank Mandiri. Dengan kata lain, jika kredit yang besar yang telah disalurkan tidak diatur dengan baik, maka ini akan berpotensi untuk mendatangkan kerugian pada Bank Mandiri. Untuk itu, rasio kedua yaitu pengelolaan kredit yang ditunjukkan oleh rasio kredit bermasalah haruslah diukur untuk melihat seberapa baik Bank Mandiri mengelola kredit yang disalurkan.

2. Rasio kredit bermasalah

Menurut Peraturan Bank Indonesia Nomor 15/2/PBI/2013 tentang Penetapan Status dan Tindak Lanjut Pengawasan Bank Umum Konvensional, untuk mendukung terciptanya stabilitas sistem keuangan maka Bank Indonesia berhak untuk melakukan pengawasan terhadap bank-bank konvensional. Salah satu kriteria yang menyatakan bahwa bank konvensional akan diawasi secara intensif adalah apabila rasio kredit bermasalah neto sudah berada pada rasio 5\% dari total kredit yang diberikan. Nilai 5\% mengindikasikan bahwa bank akan menghadapi masalah dalam menagih kredit yang diberikan kepada para debitor.

Tabel D.1menunjukkan bahwa rasio kredit bermasalah menunjukkan adanya penurunan dari tahun 2011 ke 2012 dari 2.20\% menjadi 1.90\%. Hal ini mengindikasikan bahwa aset telah dikelola dengan baik.Jadi, walaupun pada rasio kredit yang diberikan terhadap aktiva produktif menunjukkan adanya peningkatan yang berarti risiko untuk mengalami kerugian naik, namun rasio kredit bermasalah menunjukkan penurunan.Itu artinya kredit yang diberikan dapat dikelola dengan baik sehingga dapat memberikan keuntungan yang besar bagi Bank Mandiri.

\section{AnalisisManagement Quality}

Rasio BOPO (beban operasional terhadap pendapatan operasional) sebagai salah satu rasio pengeluaran akan digunakan untuk mengukur kinerja manajemen dalam efektifitas dan efisiensi biaya untuk menghasilkan profit.

Hasil penghitungan rasio BOPO dari 2011 dan 2012 sebagaimana diperlihatkan pada Tabel D.1menunjukkan bahwa dibandingkan tahun 2011, Bank Mandiri telah lebih efisien dalam menggunakan biaya operasional untuk menghasilkan pendapatan operasional. Rasio BOPO turun dari 54.01\% di tahun 2011 menjadi 53.20\% di tahun 2012.Sebagai ukuran yang digunakan untuk mengukur kualitas manajemen Bank Mandiri, maka dapat ditarik kesimpulan bahwa kualitas manajemen Bank Mandiri mengalami peningkatan dibandingkan tahun sebelumnya.

\section{AnalisisEarnings Quality}

Analisis terhadap kualitas earnings akan dilakukan dengan menggunakan rasio imbal hasil ratarata aset (ROA) dan imbal hasil rata-rata ekuitas (ROE).

1. Rasio imbal hasil rata-rata aset (ROA)

ROA adalah rasio yang menghitung efektivitas penggunaan aset dalam menghasilkan laba bersih.Secara umum, rasio yang besar menunjukkan penggunaan aset yang efektif. Dengan kata lain, aset yang ada telah dimanfaatkan untuk mendatangkan laba yang besar.

Tabel D.1 menunjukkan imbal hasi rata-rata yang dihasilkan dari penggunaan semua aset perusahaan. Dari tahun 2011 ke tahun 2012, ROA menunjukkan adanya peningkatan, yaitu dari $2.22 \%$ menjadi $2.44 \%$ yang dapat mengindikasikan bahwa aktiva perusahaan telah digunakan dengan lebih baik dari tahun sebelumnya.Aset mengalami peningkatan dan 
peningkatan itu dapat dimaksimalkan perusahaan dengan menghasilkan laba bersih yang lebih tinggi di tahun 2012 dibandingkan dengan tahun 2011.

2. Rasio imbal hasil rata-rata Ekuitas (ROE)

Rasio ini menunjukkan bagaimana modal perusahaan menghasilkan imbal hasil ratarata. Data hasil olahan ROE sebagaimana pada Tabel D.1 menunjukkan pemaksimalan pengelolaan modal Bank Mandiri dari 19.55\% di tahun 2011 menjadi $20.26 \%$ di tahun 2012.Bertambahnya jumlah modal telah digunakan oleh bank sehingga menghasilkan laba yang lebih besar dibandingkan pada tahun 2011.

Dengan demikian, dapat disimpulkan bahwa baik aset maupun modal perusahaan telah mampu menghasilkan laba dan dengan demikian perusahaan akan mampu untuk menjalankan operasinya pada saat ini maupun punya prospek yang baik untuk waktu yang akan datang.

\section{AnalisisLiquidity}

Berdasarkan Tabel D.1 dapat disimpulkan bahwa Bank Mandiri mempunyai risiko likuiditas yang tinggi karena adanya peningkatan dari tahun sebelumnya $(80.06 \%$ pada tahun 2011 menjadi $86.48 \%$ pada 2012).Kenaikan ini menunjukkan adanya kecenderungan bank untuk memberikan proporsi yang besar dari aset mereka ke dalam bentuk pinjaman.Resiko bank ini mengalami peningkatan.Akan tetapi, risiko ini dapat diminimalisirseperti yang ditunjukkan oleh penurunan NPL seperti pada pembahasan di atas.Artinya, potensi LDR berubah menjadi resiko yang merugikan telah diminimalisir.Itu berarti kredit yang diberikan telah dikelola dengan baik dan mendatangkan keuntungan bagi perusahaan.

Secara keseluruhan dapat disimpulkan bahwa kinerja keuangan PT Bank Mandiri (Persero) Tbk yang diukur dengan rasio CAMEL menunjukkan hasil yang baik.

\section{E.KESIMPULAN DAN SARAN}

\section{Kesimpulan}

Kualitas penerapan Good Corporate Governance oleh PT Bank Mandiri (Persero) Tbk berada pada kategori "sangat baik" namun sementara mengalami penurunan kualitas seperti yang ditunjukkan oleh kenaikannilai komposit dari 1.08 (tahun 2011) menjadi 1.48 (tahun 2012).

Kinerja PT Bank Mandiri (Persero) Tbk seperti yang ditunjukkan oleh rasio-rasio CAMEL baik dan menguntungkan.Hal ini dapat dilihat dari rasio kecukupan modal yang lebih tinggi dari yang diwajibkan pemerintah.Pengelolaan aset juga menunjukkan hal yang baik dimana walaupun pinjaman yang diberikan meningkat (naiknya resiko kredit), namun rasio kredit bermasalah malah turun.Selanjutnya, manajemen juga menunjukkan keefektifan dalam pengelolaan perusahaan sebagaimana diindikasikan oleh rasio BOPO.Analisa rentabilitas juga menunjukkan efektifitas pengelolaan aset dan modal yang baik seperti ditunjukkan oleh naiknya ROA dan ROE dari tahun 2011 ke tahun 2012. Yang terakhir, rasio likuiditas dapat dikelola dengan baik oleh bank.

\section{Saran}

Melalui hasil penelitian ini, penulis memberikan beberapa saran kepada PT Bank Mandiri (Persero) Tbk. Yang pertama meningkatkan kualitas penerapan GCG dengan cara penyempurnaan prosedur penanganan benturan kepentingan dan prosedur kepatuhan bank, meningkatkan kualitas pengendalian internal, serta lebih proaktif dalam membuat penyesuaian dengan perubahan-perubahan lingkungan yang dinamis.

Selain itu, Bank Mandiri juga hendaknya mempertahankan bahkan meningkatkan pengontrolan terhadap kredit yang diberikan untuk mengantisipasi munculnya resiko likuiditas. 


\section{DAFTAR PUSTAKA}

Baral, K.J. (2005). Health Check-up of Commercial Banks in the Framework of CAMEL: A Case Study of Joint Venture Banks in Nepal. The Journal of Nepalese Business Studies, II.

Bank Indonesia.(2004). Sistem Penilaian Tingkat Kesehatan Bank Umum di Indonsia.Peraturan Bank Indonesia Nomor 6/10/PBI/2004.Bank Indonesia.

. (2006). Perubahan Atas Peraturan Bank Indonesia Nomor 8/4/PBI/2006 Tentang Pelaksanaan Good Corporate Governance Bagi Bank Umum.Peraturan Bank Indonesia Nomor 8/14/PBI/2006. Bank Indonesia.

.(2013) Pelaksanaan Good Corporate Governance Bagi Bank Umum. Surat Edaran Bank Indonesia Nomor15/15/DPNP tanggal 29 April 2013. Bank Indonesia

Hays, F.H., De Lurgio, S.A., \& Gilbert Jr., A.H. (2009).Efficiency Ratios and Community Bank Performance.Journal of Finance and Accountancy, 1, 1-15

IICG.(2002). Penilaian Penerapan Prinsip GCG Pada Perusahaan di Indonesia Tahun 2002. IICG: Jakarta

Institut Bankir Indonesia.(1999). Kamus Perbankan, Jilid Dua.

King, R. G., \& Levine, R. (1993).Finance, Entrepreneurship and Growth.Journal of Monetary Economics, 32(3), 513-542.

Koch, T. W., \& Scott, M. S.( 2003). Bank Management $5^{\text {th }}$ Ed. United States of America: South-Western

Komite Cadbury (1992). The Business Roundtable, Staement on Corporate Governance (Washington DC., 1997)

Kuncoro, M. P. (2006). Strategi Bagaimana Meraih Keunggulan Kompetitif. Erlangga

OECD 2010.Global Corporate Governance Forum.Background document. Retrieved from http://www.oecd.org/dataoecd/63/60/46435512.pdf

Sarker, A. A. (2006). CAMELS Rating System in the Context of Islamic Banking: A Proposed "S" for Shariah Framework. Journal of Islamic Economics, Banking, and Finance, 2.

Singh, D., \& Kohli, G. (2006).Evaluation of Private Sector Banks in India.Journal of Management Research, 6(2), 84-101.

Syahyunan.(2002). Analisis Kualitas Aktiva Produktif Sebagai Salah Satu Alat Ukur Kesehatan Bank.Jurnal Fakultas Ekonomi Universitas Sumatera Utara.

Undang-Undang Republik Indonesia No. 10 Tahun 1998.Perubahan atas Undang-Undang No. 7 Tahun 1992 Tentang Perbankan. 